Check for updates

The BMJ

Cite this as: BMJ 2021;373:n1374 http://dx.doi.org/10.1136/bmi.n1374 Published: 27 May 2021

\section{Covid-19: Thousands died needlessly from UK pandemic response, says PM's former aide}

\author{
Gareth lacobucci
}

The government and senior officials fell "disastrously short" in their response to the covid-19 pandemic, the prime minister's former chief aide has said.

In a lengthy session giving evidence to the parliamentary health and science select committees' inquiry into lessons learnt from the pandemic on 26 May, Dominic Cummings acknowledged that thousands of people died needlessly as a result of the government's mistakes.

Boris Johnson's former chief adviser told MPs that the government had been too slow to get onto a "war footing" in January and February 2020, had no initial plan beyond herd immunity, and had been too slow to impose lockdowns in March and again in the autumn.

"The truth is that senior ministers, senior officials, senior advisers like me fell disastrously short of the standards that the public has a right to expect of its government in a crisis like this," Cummings told MPs. "When the public needed us most the government failed. I would like to say to all the families of those who died unnecessarily how sorry I am for the mistakes that were made and for my own mistakes at that.”

Cummings was highly critical of the prime minister, who he said was "unfit for the job." The former aide claimed that Johnson initially dismissed covid-19 as a "scare story" and was later reluctant to lock down again in September 2020 despite the clear evidence from the first wave.

“There's this great misunderstanding people have that because it [covid] nearly killed him therefore he must have taken it seriously," said Cummings. "But in fact, after the first lockdown, he was cross with me and others with what he regarded as basically pushing him into the first lockdown.”

Cummings was also scathing about the health secretary, Matt Hancock, whom he accused of lying on several occasions and said should have been fired. ${ }^{1}$

He called for the public inquiry into the handling of the pandemic to start as soon as possible. "Tens of thousands of people died who didn't need to die," he said. "There's absolutely no excuse for delaying [an inquiry]. A lot of the reasons for why that happened are still in place."

Cummings later said that disagreements between himself and Johnson over the response to the pandemic ultimately led to Cummings's departure from government. He said that Johnson was fixated on reopening the economy, regretted the first lockdown, and ignored advice from him, the chief scientific officer, and the chief medical officer to impose a "circuit breaker" lockdown last September when covid cases were surging.

"He didn't think in July, or September, 'Thank goodness we did the first lockdown, it was obviously the right thing to do.' His argument then was, 'We shouldn't have done the first lockdown, and I'm not going to make the same mistake again,'” Cummings said.

He also confirmed that herd immunity was the government's initial strategy in March 2020 before the first lockdown. Cummings said, "It was either herd immunity by September, or by January after a second peak. That was the assumption up until Friday 13 March. It was regarded as an unavoidable fact.”

He added, "The fundamental groupthink problem was being trapped in the idea that there was only a choice between herd immunity by September or herd immunity by January (2021), whereas in fact the right way of looking at it was: we can avoid both."

Speaking at prime minister's questions in response to Cummings's claims, Johnson told MPs, “The handling of this pandemic has been one of the most difficult things this country has had to do for a very long time, and none of the decisions have been easy.

"To go into a lockdown is a traumatic thing for a country, to deal with a pandemic on this scale has been appallingly difficult, and we have at every stage tried to minimise loss of life, to save lives, to protect the NHS, and we have followed the best scientific advice that we can."

Dominic Cummings on ...

The government's lack of preparation

“We didn't act like it was important in February, let alone January. Number 10 and the government were not working on a war footing in February. It wasn't until the last week of February there was any sense of urgency."

The PM's attitude to covid

"In February the prime minister regarded this as just a scare story. He described it as the new swine flu. The view of various officials inside Number 10 was if we have the PM chairing Cobra meetings and he just tells everyone, 'It's swine flu: don't worry about it. I am going to get Chris Whitty to inject me live on TV with coronavirus so everyone realises it's nothing to be frightened of,' that would not help actual serious planning."

Herd immunity

"The cabinet secretary [Mark Sedwill] said, 'Prime Minister, you should go on TV tomorrow and explain to people the herd immunity plan, and that it's like the old chicken pox parties. We need people to get this disease because that's how we get herd immunity by September.' I said, 'Mark, you have got to stop using this chicken pox analogy, it's not right,' and he said, 'Why?' and Ben Warner [a Number 10 aide] said, 'Because chicken pox 
is not spreading exponentially and killing hundreds of thousands of people."”

\section{Explaining the need for a lockdown to the PM in March 2020}

"We had graphs showing that even in the best case scenario, with the official plan, we were going to completely smash through the capacity of the NHS. On the evening of Friday 13 March we said, 'We are going to have to sit down with the PM and explain to him that we are going to have to ditch the whole official plan and we are heading for the biggest disaster this country has seen since 1940."”

\section{Not learning from east Asia}

"The experience of places like Singapore and Taiwan was completely disregarded by the system. One of the critical things that was completely wrong in the whole official thinking, in SAGE and in the Department of Health in February and March, was first of all the British public will not accept a lockdown, [and] secondly the British public will not accept a kind of east Asian style track and trace system and the infringement of liberty. Those two assumptions were completely central to the official plan and were both obviously completely wrong."

\section{The PM's dislike of lockdown}

"The view from the PM was that the economic consequences would be much worse than the health [consequences]. His argument after [the first lockdown] was, "I should have been the mayor of Jaws and kept the beaches open."”

\section{The failings of senior leaders}

"There are brilliant officials all over the place, but the system tends to weed them out of senior positions. It was lions led by donkeys over and over again."

1 lacobucci G. Covid-19: PM's former chief aide accuses health secretary of lying over PPE and access to treatment. BMJ2021;373:n1369.

This article is made freely available for use in accordance with BMJ's website terms and conditions for the duration of the covid-19 pandemic or until otherwise determined by BMJ. You may use, download and print the article for any lawful, non-commercial purpose (including text and data mining) provided that all copyright notices and trade marks are retained. 